\title{
SUMBER AGAMA DALAM PERSPEKTIF PSIKOLOGIS
}

\author{
Syaiful Hamali \\ IAIN RAden Intan Lampung \\ syaiful_hamali@yahoo.co.id
}

\begin{abstract}
Abstrak
Tulisan ini membahas secara konseptual tentang berbagai kebutuhan dasar manusia sebagai sumber kehidupan bagi manusia dalam ranah psikologis. Melalui eksplorasi-psikologis diperoleh fakta bahwa ada berbagai macam kemampuan dasar yang dimiliki manusia yang dapat dikembangkan guna menunjang hidup dan kehidupannya. Sedangkan melalui pengamatan potensi-diri diperoleh fakta bahwa dalam diri manusia tersimpan sejumlah kemampuan bawaan, termasuk diantaranya adalah potensi untuk percaya pada supernatural (agama). Sinergi antara eksplorasi-psikologis dengan potensi-diri manusia akan membentuk sumber-sumber keyakinan terhadap agama secara psikologis. Karena itu, dalam konteks ini, tanpa adanya wahyu pun sesungguhnya manusia akan mampu mengenal Tuhan. Wahyu hanya berfungsi sebagai pemberitaan dari alam metafisika yang turun kepada manusia untuk menerangkan tentang Tuhan sekaligus kewajiban-kewajiban yang harus dilakukan manusia terhadap Sang Khalik maupun sesamanya. Singkatnya secara psikologis, siapa mengenal dirinya, niscaya ia akan mengenal Tuhannya. Karena itu manusia wajib mempercayai dan meyakini akan adanya Tuhan serta melaksanakan ajaran-ajaran agama dalam kehidupannya.
\end{abstract}

\begin{abstract}
THE SOURCE OF RELIGION IN PSYCHOLOGICAL PERSPECTIVE: This paper discusses the conceptual basis of the basic needs of man as a source of life from the psychological perspectives. Through a psychological exploration one can find various kinds of basic capabilities of human beings that can be developed to support their life and livelihood. Whereas from the potentials of self observation one also can find innate ability of humans, including
\end{abstract}


the potentials to belief in supernatural (religion). The synergy between psychological exploration and human potentials will establish psychological sources of religious belief. Therefore, seeing from this perspective, man will still be able to know God in the absence of any revelation. Revelation only serves as a means of communication from the metaphysics nature down to man, to explain about God and the obligations that must be performed by man in relation to the divine beings. In short, those who knew himself, surely will know his Lord. Therefore, humans must trust and believe in God and implement the teachings of religion in his life.

Kata kunci : Sinergi, eksploratif-pskologis, potensi-diri.

\section{A. Pendahuluan}

Agama menyangkut kehidupan batin manusia, oleh sebab itu kesadaran beragama dan pengalaman keagamaan yang dialami oleh seseorang lebih menggambarkan sisi-sisi kehidupan batin yang berkaitan erat dengan sesuatu yang dianggap sakral atau yang bersifat transenden. Untuk itu manusia berusaha dan berupaya mencari berbagai sumber agama dalam dirinya sebagai pedoman dalam kehidupannya.

Dalam psikologi, sumber agama terdiri dari teori monistik dan teori fakulti. Teori monistik menegaskan bahwa sumber kejiwaan agama pada manusia berasal dari satu sumber. Sedangkan teori fakulti mengemukakan bahwa sumber kejiwaan agama pada manusia merupakan gabungan dari beberapa fungsi kejiwaan yang terdapat dalam diri manusia. Selain itu, dalam diri manusia terdapat emosi (perasaan dalam) sebagai sumber tingkah laku, termasuk tingkah laku manusia beragama. Para ahli psikologi agama menjelaskan bahwa emosi keagamaan adalah gejolak kejiwaan yang terdapat dalam diri manusia yang mendorong manusia bertingkah laku keagamaan. Peristiwa-peristiwa kejiwaan ini dapat dilihat pada setiap tingkah laku keagamaan yang menunjukkan ketaatan seseorang terhadap agamanya; karena semakin kuat emosi keagamaan yang dimiliki oleh seseorang maka semakin baik pengamalan keagamaanya. Sebaliknya, semakin lemah emosi keagamaan yang dimiliki seseorang maka akan kurang pengamalan keagamaanya. 
Emosi merupakan gejolak atau dorongan, yaitu gerakangerakan jiwa yang terdapat dalam diri manusia yang berfungsi sebagai penyesuaian diri terhadap lingkungan. Emosi keagamaan itu termasuk unsur pokok dalam setiap agama. Sebagaimana ditulis Koentjaraningrat bahwa ada 4 unsur pokok setiap religi, yaitu: a) Emosi keagamaan; b). Sistem kepercayaan, c) Sistem upacara keagamaan; d) Kelompok keagamaan. ${ }^{1}$ Sehingga agama memiliki seperangkat aturan dan ketentuan bagi manusia untuk mencapai kebahagian didunia dan diakhirat. Justru itu manusia harus mengekspresikan emosional psikologisnya dalam bentuk perbuatanperbuatan dalam hidupnya. Harun Nasution menulis unsur-unsur penting dalam agama di antaranya adalah, ... Respon yang bersifat emosionil dari manusia. Respon itu bisa mengambil bentuk perasaan takut seperti yang terdapat dalam agama primitif atau perasaan cinta seperti yang terdapat dalam agama-agama monoteisme... ${ }^{2}$

Selanjutnya, tulisan ini hanya mengemukakan secara konseptual tentang berbagai kebutuhan-kebutuhan dasar manusia sebagai sumber keagamaan bagi manusia dalam kajian psiklogis.

\section{B. Kebutuhan Dasar Manusia}

Secara psikologis, kebutuhan dasar manusia merupakan segala sesuatu yang berkenaan dengan kebutuhan jasmani dan kebutuhan rohani. Dalam psikologi kebutuhan itu timbul dari dalam diri manusia yang berasal dari Id. Hanna Djumhana Bastamam mengungkapkan bahwa ada pun yang terkandung di dalam id adalah berbagai potensi yang dibawa sejak lahir, insting-insting dan nafsu-nafsu primer, sumber energi psikis yang memberi daya kepada Ego dan Super Ego untuk menjalankan fungsinya. ${ }^{3}$ Dalam struktur kepribadian the id berfungsi untuk menghindarkan diri dari rasa tidak enak dan mengejar atau mencari berbagai kenikmatan untuk

${ }^{1}$ Koentjaraningrat, Beberapa Pokok Antropologi Sosial, cet. ke-4, (Jakarta: PT. Dian Rakyat 1985), h. 230.

${ }^{2}$ Harun Nasution, Islam Ditoinjau Dari Beberapa Aspek, cet. ke-2, (Jakarta: UI. Press, 1984), h. 11.

${ }^{3}$ Hanna Djumhana Bastamam,Integrasi Psikologi Dengan Islam Menuju Psikologi Islami, cet. ke-2, (Yogyakarta: Pustaka Pelajar, 1994), h. 50.

${ }^{4}$ Zakiah Daradjat, Peranan Agama Dalam Kesehatan Mental, (Jakarta: Gunung Agung, 1970), h. 12. 
memenuhi kebutuhan hidupnya, karena itu bagi the id berlaku prinsip kenikmatan. Dalam psikologis, the Id dikenal sebagai penggerak tingkah laku manusia

Zakiah Daradjat dalam bukunya "Peranan Agama Dalam Kesehatan Mental" membagi kebutuhan manusia itu atas dua kebutuhan pokok: 1) Kebutuhan Primer yaitu; kebutuhan jasmani; makan, minum, seks dan sebagainya (Kebutuhan ini didapat manusia secara fitrah tanpa dipelajari). 2) Kebutuhan Sekunder atau kebutuhan rohaniah: Jiwa dan sosial (Kebutuhan ini hanya terdapat pada manusia dan sudah dirasakan sejak manusia kecil). Sedangkan Jalaluddin dalam bukunya "Psikologi Agama" menulis pendapat Zakiah bahwa selain kebutuhan jasmani dan kebutuhan rohani manusia pun mempunyai suatu kebutuhan atau adanya kebutuhan akan keseimbangan dalam kehidupan jiwanya agar tidak mengalami tekanan ${ }^{4}$. Dalam kehidupan masyarakat, di antara mereka lebih mengutamakan kehidupan jasmaniah (kebutuhan dunia) dari pada kebutuhan rohaniah (kebutuhan akhirat). Selain itu Selain itu kehidupan mereka hanya diukur dengan kemewahan dan kekayaan yang dimilikinya, mereka lupa bahwa kehidupan akhirat merupakan tempat kembalinya semua manusia, seyogyanya mereka harus mempersiapkan diri untuk kepentingan akhirat. Pada hal kedua bentuk kehidupan itu harus balance atau selaras dalam kehidupan manusia.

Abraham H. Maslow, seorang psikolog kontemporer mengemukakan teori tingkatan kubutuhan (need-hierarchy-theory) bahwa kebutuhan manusia pada dasarnya bertingkat-tingkat, mulai dari kebutuhan yang paling bawah sampai ke tingkatan yang paling tinggi. Kebutuhan pada tingkatan yang lebih tinggi tidak mungkin timbul sebelum kebutuhan yang lebih mendasar terpenuhi. ${ }^{5}$

Kebutuhan dasar manusia itu meliputi, yaitu; Pertama, kebutuhan fisilogis adalah kebutuhan dasar yang harus dipenuhi manusia untuk bisa hidup seperti; makan, minum, seks dan sebagainya. Kedua, kebutuhan rasa aman (safety) yaitu kebutuhan

${ }^{4}$ Jalaluddin, Psikologi Agama, cet. ke-1, (Jakarta: PT. Raja Grafindo Persada, 1996), h. 6.

${ }^{5}$ Djamaluddin Ancok dan Fuat Nashori Suroso, Psikologi Islami, cet. ke-1 (Yogyakarta: Pustaka Pelajar, 1994), h. 49. 
manusia untuk memperoleh rasa aman, orang ingin bebas dari rasa ketakutan dan kecemasan dalam hidupnya. Ketiga, kebutuhan akan rasa kasih sayang. Perasaan ingin memiliki dan dimiliki oleh orang lain, kelompok, atau masyarakat adalah merupakan sesuatu yang dibutuhkan oleh setiap manusia. Keempat, kebutuhan akan adanya rasa harga diri. Agar dirinya dihargai sebagai manusia maka sebagai warga negara seseorang akan berbuat sesuatu yang berguna bagi dirinya, kelompok atau bangsanya, dimana pada tahap ini orang ingin buah fikirannya dihargai. Kelima, kebutuhan akan aktualisasi diri. Pada tingkatan ini manusia ingin berbuat sesuatu semata-mata karena dorongan dari dalam diri manusia itu sendiri. Dia tidak lagi menuntut atau mengharapkan penghargaan orang lain atas apa yang diperbuatnya, sesuatu yang ingin dikejar dalam kebutuhan tingkatan ini adalah keindahan (beautiful), kesempurnaan (perfecting), keadilan (justice) dan kebermaknaan dalam hidup.

Realitas dalam masyarakat menunjukkan bahwa kebutuhan manusia itu berbagai macam bentuk dan tingkatannya, bahkan di antara mereka tinggal dalam satu tingkatan cukup lama mereka telah menghabiskan pikiran, tenaga dan usia yang cukup panjang agar dapat pindah ke tingkatan berikutnya, namun usahanya untuk pindah ketingkatan kehidupan berikutnya belum juga berhasil, hal ini disebabkan mereka masih berada atau hidup dibawah garis kemiskinan. Masalah kemiskinan bukanlah masalah yang baru, karena lima belas abad yang lalu Nabi Muhammad saw telah menginformsikan kepada umatnya melalui hadisnya yang artinya; kemiskinan itu akan mendatangkan kekufuran. Dalam kenyatannya bahwa orang-orang yang miskin hanya menghabiskan waktunya untuk dapat memenuhi kebutuhan fisiologinya, sehingga tidak terpikirkan lagi kebutuhan-kebutuhan lainnya, sedangkan kebutuhan manusia untuk beragama terdapat dalam tingkatan kelima dari teori tingkatan kebutuhan manusia, Seperti yang diungkapkan Djamaluddin Ancok dkk bahwa kebutuhan untuk beragama menduduki peringkat kelima dalam teori kebutuhan Maslow, yaitu kebutuhan aktualisasi diri. ${ }^{6}$

${ }^{6}$ Ibid., h. 50. 


\section{Motivasi Manusia Beragama.}

Motivasi merupakan suatu kekuatan yang mendorong manusia untuk melakukan suatu pekerjaan atau tindakan. Dalam psikologi motivasi berarti rangsangan, dorongan atau pembangkit tenaga manusia bagi terjadinya suatu tingkah laku. Nico Syukur Diester dalam bukunya menulis bahwa motivasi adalah dorongan psikologis untuk mengejar sesuatu. ${ }^{7}$ Maka motivasi manusia beragama merupakan dorongan atau kekuatan jiwa keagamaan yang memberikan arahan terhadap aktivitas manusia untuk melaksanakan ajaran-ajaran agamanya. Beberapa faktor yang mendorong manusia untuk menganut agama dalam hidup dan kehidupannya, antara lain adalah:

\section{Mengatasi Frustrasi}

Frustrasi merupakan kondisi kejiwaan manusia tatkala menemui kesulitan dan hambatan atau kegagalan dalam mencapai tujuannya, sehingga harapannya menjadi sirna dan menimbulkan kecewa dalam hidupnya. Hal ini dijelaskan Kartini Kartono bahwa "Frustrasi adalah keadaan di mana satu kebutuhan tidak bisa terpenuhi dan tujuan tidak bisa tercapai, sehingga orang kecewa dan mengalami satu barrier atau halangan dalam usahanya mencapai satu tujuan." Abdul Aziz Ahyadi, dalam bukunya Psikologi Agama Kepribadian Muslim Pancasila menulis dampak frustrasi pada manusia yaitu, bahwa; Pemenuhan kebutuhan yang tidak terpuaskan disebabkan adanya frustasi yang dialami manusia di dalam berbagai bidang kehidupan dan dapat menimbulkan manusia bertingkah laku keagamaan, karena manusia yang mengalami frustasi akan berusaha mengatasinya. ${ }^{9}$

Frustrasi yang dialami manusia dapat dilihat dari dua sisi; Pertama, frustrasi yang dialami manusia dapat menimbulkan perasaan yang bersifat negatif, karena frustrasi yang dialaminya itu akan menimbulkan perasaan sedih dan putus asa bagi dirinya.

\footnotetext{
${ }^{7}$ Nico Syukur Diester, Pengalaman dan Motivasi Beragama, Pengantar Psikologi Agama, (Jakarta: LEPPENAS, 1982), h. 124.

${ }^{8}$ Kartini Kartono dan Jenny Andari, Hygiene Mental Kesehatan Mental Dalam Islam, cet. ke-4, (Bandung: Mandar Maju, 1982), h. 105.

${ }^{9}$ Abdul Aziz Ahyadi, Psikologi Agama Kepribadian Muslim Pancasila, (Bandung: Sinar Baru, 1999), h. 12.
} 
Sehingga mereka tidak bergairah untuk melakukan pekerjaannya dan hanyut dalam kesedihan. Kedua, frustrasi yang dialami oleh seseorang dapat menimbulkan perasaan yang bersifat positif, karena frustrasi yang dialminya itu mendorong manusia mencari metode baru untuk mengatasi frustrasi yang sedang dihadapinya dengan kata lain frustrasi yang menimpa seseorang dapat membentuk adaptasi baru yang menguntungkan kehidupan batinnya, justru itu dalam hidupnya ia selalu mengarahkan keinginannya untuk mendekatkan dirinya kepada Sang Khalik agar segala kenginannya dikabulkan oleh Tuhan.

Sigmund Freud, tokoh psikoanalisa menjelaskan bahwa agama memang bersifat fungsional belaka. Agama itu jawaban atas frustrasi yang dialami manusia di berbagai bidang kehidupan. Manusia bertindak religius karena ia mengalami frustrasi. ${ }^{10}$ Dengan demikian, frustrasi yng dialami seseorang dapat menimbulkan perilaku religius, karena dalam agama manusia mendapatkan solusi untuk bisa mengatasi berbagi problem yang dihadapinya

\section{Mengatasi Perasaan Takut.}

Kartini Kartono menulis bahwa ketakutan atau kecewaan yang abnormal, dan tidak rasional tidak bisa dikontrol terhadap sesuatu situasi atau obyek tertentu yang menimbulkan ketakutan dan kekecewaan. ${ }^{11}$ Ketakutan merupakan sinyal bagi manusia atau gejala-gejala sebagai peringatan kepada manusia bahwa dasardasar eksistensinya berada di luar kekuasaan manusia yang tidak bisa diatasinya sendiri, karena menurut mereka masih ada suatu kekuatan yang lebih tinggi dari kekuatan manusia itu sendiri yaitu Tuhan. Setiap agama selalu mengajarkan umatnya untuk mendekatkan dirinya kepada Tuhan. Ketakutan-ketakutan yang tidak ada obyeknya ini selalu menghantui jiwa manusia dan dapat menimbulkan perasaan was-was terhadap sesuatu yang tidak jelas. Sebaliknya ketakutan yang ada obyek yang ditakuti itu dan dapat dilihat akibatnya bagi orang-orang yang melanggarnya, ketakutan seperti ini merupakan peringatan bagi manusia agar lebih berhatihati dalam bekerja karena melanggar aturan-aturan yang telah

\footnotetext{
${ }^{10}$ Diester, Pengalaman..., h. 82.

${ }^{11}$ Kartini Kartono dan Jenny Andari, Hygiene Mental..., h. 72.
} 
ditetapkan akan berakibat fatal bagi manusia yang melanggarnya, misalnya; ketakutan manusia bila melanggar peraturan lalu lintas sebab melanggar aturan lalu lintas akan mengkibatkan terjadinya kecelakaan bagi orang yang melanggar aturan tersebut.

Nico Syukur Diester menjelaskan bahwa sejauh ketakutan itu menyertai frustrasi (takut mati, takut kesepian) maka secara tidak langsung ketakutan itu mempengaruhi timbulnya tindakan keagamaan ${ }^{12}$. Ketakutan yang tidak ada obyeknya merupakan ketakutan yang khas pada manusia sebagai simbol-simbol dari konflik jiwa yang terjadi pada manusia, sedangkan frustrasi yang dibarengi dengan ketakutan dan kecemasan tentang tujuannya tidak tercapai maka ketakutan yang dialaminya itu akan mempengaruhi terjadinya perbuatan-perbuatan keagamaan.

\section{Menjaga Kesusilaan}

Driyarkara menulis bahwa kesusilaan adalah suatu nilai, hal ini adalah suatu kebenaran yang tidak dapat dibantah. Kesusilaan berarti nilai, menjalankan kesusilaan berarti melaksanakan nilai. ${ }^{13}$ Dalam masyarakat, manusia senantiasa mengalami perubahanperubahan. Dalam hidupnya. terjadinya perubahan-perubahan itu berpengaruh terhadap nilai-nilai dan tingkah laku masyarakat. Perubahan itu ada dua bentuk; Pertama, berbentuk positif, yaitu perubahan-perubahan yang terjadi dalam masyarakat telah diatur atau direncanakan terlebih dahulu oleh seseorang atau sekelonpok orang yang menginginkn perubahan itu. Sehingga perubahan ini mempunyai konsep, bentuk dan tujuan yang hendak dicapai. Kedua, berbentuk negatif, yaitu terjadinya perubahan-perubahan dalam masyarakat tidak direncanakan oleh seseorang, kelompok atau masyarakat, perubahan itu hanya terjadi secara kebetulan atau seketika, terjadinya perubahan ini berada diluar jangkauan, pengawasan kelompok atau masyarakat, akhirnya perubahan yang terjadi akan menimbulkan kekacauan, tindak kekerasan sehingga melanggar nilai-nilai agama dan norma-norma yang berlaku dalam masyarakat..

Kesusilaan dan norma-norma yang terdapat dalam masyarakat sangat penting kedudukannya dalam menciptakan

\footnotetext{
${ }^{12}$ Diester, Pengalaman..., h. 82.

${ }^{13}$ Driyarkara, Percikan Filsafat, (Jakarta: Pembangunan, 1978), h. 16.
} 
kedamaian dan ketenteraman, jika kedua unsur itu tidak lagi berarti bagi manusia, mereka akan mencari agama sebagai landasan kehidupannya. Diester menulis bahwa agama berfungsi sebagai institusi yang mengatur hidup dan kehidupan manusia karena agama dapat diabadikan kepada tujuan yang bukan religius melainkan yang bersifat moral dan sosial, ${ }^{14}$ Agama akan mengakomodir seluruh kepentingan masyarakat terutama hal-hal yang berhubungan dengan moral dan sosial baik hubungan dengan sesamanya dan lingkungannya maupun hubungan manusia dengan Khaliknya dengan berbagai konsep ajarannya.

Elizabeth K. Nottingham mendeskripsikan keberadaan agama dalam masyarakat Amerika untuk menanamkan nilai-nilai agama pada anak-anaknya. Menurutnya bahwa: kebanyakan orang tua bangsa Amerika barangkali masih beranggapan bahwa nilainilai agama tradisional dan nilia-nilai serupa yang diperbarui dalam versi baru merupakan landasan membangun karakter yang dapat dibenarkan. ${ }^{15}$ Masyarakat modern masih menganggap keberadaan agama sangat penting dalam menanamkan serta membentuk nilainilai dan norma-norma masyarakat bagi anak-anak mereka sebagai pedoman hidup dimasa mendatang.

4. Memuaskan Intelek

Agama dapat memuaskan intelek manusia, karena agama mampu memberikan jawaban terhadap berbagai pertanyaan yang tidak bisa dijawab oleh rasio atau intelek manusia, misalnya pertanyaan-pertanyaan berkenaan dengan: Siapa saya... ? Dimana saya sekarang...? Dan kemana saya nantinya ? begitulah sekelumit pertanyaan yang selalu menggangu fikiran atau akal manusia, secara kejiwaan bila persoalan-persoalan itu tidak bisa dijawab niscaya akan menimbulkan ketegangan dan kegelisahan bagi manusia. Nico Syukur Diester menulis bahwa agama memberikan kerangka acuan kepada manusia sehingga ia dapat menyesuasikan dirinya dalam kehidupan. ${ }^{16}$ Bila pertanyaan-pertanyaan itu tidak bisa diselesaikan oleh logika manusia, agama akan menyelesaikan dengan berbagai

${ }^{14}$ Diester, Pengalaman..., h. 112.

${ }^{15}$ Elizabeth K. Nottingham, Agama dan Masyarakat, Suatu Pengantar Sosiologi Agama, Jakarta: Raja Grafindo Persda, 1992, h. 64

${ }^{16}$ Diester, Pengalaman..., h. 118. 
solusi yang dapat diterima manusia sehingga tercipta ketenangan dan ketenteraman dalam dirinya.

Pada dasarnya manusia itu diciptakan dalam keadaan lemah, baik secara fisik maupun secara psikis, manusia tidak mampu menyelesaikan persoalan-persoalan yang dihadapinya, mereka masih mengharapkan satu kekuatan yang berada diluar dirinya yang dapat menyelesaikan persoalan-persoalannya, dalam sosiologi agama kondisi yang dialami manusia itu disebut masa kegelapan. Sebagaimana Hendro Puspito menulis bahwa; Kawasan ini disebut daerah "gelap" karena rasio manusia tidak sanggup menangkap hakekat (substansi) kekuatan "luar" karena "Dia“ itu diluar jangkauan manusia. ${ }^{17}$ Sehingga hubungan antara manusia dengan Khaliknya terpisah. Untuk menetralisir hubungan kedua unsur itu, manusia harus membentuk hubungan baik dengan melakukan sejumlah ritual yang harus dilaksanakan dan ditaati oleh orangorang yang hendak bertemu dengan Tuhan atau dengan sesuatu kekuatan yang berada di luar sana.

Justru itu, manusia diharuskan menanamkan keyakinan dalam dirinya bahwa ia bisa mengatasi masalah-masalah yang dihadapinya dengan bantuan yang Supernatural. Dengan demikian ia termotivasi untuk mengatasi persoalan yang dihadapinya. Hendro Puspito menambahkan bahwa: ...dengan jalan itu (merupakan bagian terpenting dari agama) manusia meyakinkan dirinya untuk sanggup mengatasi problema manusia yang paling mendasar; ketidakpastian, ketidakmampuan dan kelangkaan. ${ }^{18}$ Ketiga faktor ini yang menjadi penyebab atau yang mendorong manusia beragama, karena agama akan memberikan jawaban setiap masalah-masalah yang terjadi pada diri manusia.

\section{Teori-teori Sumber Agama Secara Psikologis}

Semua aturan-aturan dan ketentuan-ketentuan hidup manusia dapat ditemukan dalam setiap agama, yang harus dipatuhi dan ditaati manusia dalam berbagai aktivitas yang dilakukannya. Thomas F. Ode'a menulis dalam bukunya Sosiologi Agama bahwa; Agama bagi manusia telah dicirikan sebagai pemersatu, aspirasi

\footnotetext{
${ }^{17}$ Hendro Puspito, Sosiologi Agama, cet. 4, (Jakarta: Kanisius, 1988), h. 37. ${ }^{18}$ Ibid.
} 
manusia yang paling sublin, sebagai sejumlah moralitas, sebagai sesuatu yang memuliakan dan membuat manusia beradab. ${ }^{19}$ Faktorfaktor inilah yang mendorong manusia mengabdikan dirinya kepada Tuhan untuk menyelesaikan masalah-masalah yang dihadapinya

Kebutuhan manusia akan agama merupakan suatu kebutuhan kodrati bagi manusia, diantaranya adalah kebutuhan untuk mencintai dan dicintai Tuhan. Kebutuhan itu terdapat pada setiap orang, kelompok dan masyarakat mulai dari tingkat yang paling primitif sampai ke tingkat yang paling modern. Dalam merealisasikan konsep-konsep agama dalam kehidupan nyata, muncul berbagai pertanyaan yang mendasar dari manusia di antara pertanyaannya adalah; Apakah yang menjadi sumber agama bagi manusia secara psikologis ? Sebagai jawaban dari pertanyaan itu maka muncul dua bentuk teori, yaitu sebagai berikut :

\section{Teori Monistik}

Monistik merupakan suatu teori yang membicarakan konsep sumber agama secara psikologis pada manusia. Jalaluddin dalam bukunya Psikologi Agama menulis bahwa yang menjadi sumber kejiwan agama pada manusia adalah berasal dari satu sumber kejiwaan. ${ }^{20}$ Hanya saja dalam menentukan unsur-unsur yang mendasari timbulnya sumber jiwa keagamaan pada manusia itu, para ahli psikologi berbeda pendapat, di antaranya adalah:

a. Unsur Berfikir

Manusia adalah makhluk yang paling sempurna di antara makhluk yang diciptakan Tuhan karena kelahiran manusia dilengkapi dengan akal atau berfikir. Dengan berfikir manusia dapat mengembangkan dirinya dalam kehidupannya. Dengan berfikir pula manusia berusaha untuk membuka tabir-tabir kebenaran. Jalaluddin menulis pendapat Thomas Aquino bahwa yang menjadi sumber kejiwaan agama itu ialah berfikir. Manusia ber-Tuhan karena manusia menggunakan kemampuan berfikir-nya. Kehidupan beragama merupakan refleksi dari kehidupan berfikir manusia itu sendiri. Kemudian untuk memperkuat argumentasi ini Jalaluddin

${ }^{19}$ Thomas F. Ode'a, Sosilogi Agama, Suatu Pengenalan Awal. Terj. Yasogama, cet. ke-1, (Jakarta: CV. Rajawali, 1985), h. 2.

${ }^{20}$ Jalaluddin, Psikologi..., h. 54. 
mengambil pendapat Fredrich Hegel yang menjelaskan bahwa Agama adalah suatu pengetahuan yang sungguh-sungguh benar dan tempat kebenaran abadi. Berdasarkan hal itu agama sematamata merupakan hal-hal atau persoalan yang berhubungan dengan fikiran. ${ }^{21}$

Dengan demikian, berfikir adalah sumber kejiwaan agama bagi manusia, karena dengan berfikir manusia dapat mengetahui kebenaran, sedangkan kebenaran yang mutlak itu hanya berada di tangan Tuhan berarti dengan berfikir manusia bisa mengenal Tuhan. Di samping itu dengan berfikir manusia bisa mengetahui kewajibankewajiban yang harus dilakukan atau larangan-larangan yang harus ditinggalkan manusia.

b. Sense of Depend

Secara fisik manusia termasuk makhuk yang lemah, takkala manusia dilahirkan belum mampu untuk berbuat sesuatu, namun kelahirannya telah dilengkapi dengan berbagai potensi dasar yang siap untuk dikembangkan dalam hidupnya. Berangkat dari kondisi jiwa yang dialaminya itu, maka manusia menggantungkan hidupnya kepada suatu kekuatan yng lebih tinggi dari dirinya yang disebut dengan Tuhan

Berdasarkan hal ini Fredrich Schleimachir berpendapat bahwa berdasarkan rasa ketergantungan itulah timbul konsep tentang Tuhan. Manusia merasa tak berdaya menghadapi tantangan alam yang selalu dialaminya, sehingga mereka menggantungkan harapannya kepada sesuatu kekuatan yang bersifat mutlak adanya untuk membantunya dalam kesulitan. Kemudian Jalaluddin menjelaskan bahwa rasa ketergantungan mutlak ini dapat dibuktikan dalam kegiatan atau upacara keagamaan dan pengabdian para penganut agama kepada sesuatu kekuatan yang mereka sebut sebagai Tuhan. ${ }^{22}$

\section{c. Libido Seksualitas Manusia}

Libido seksual termasuk unsur kejiwaan, sekaligus sebagai sumber kejiwaan agama bagi manusia, setelah melalui proses yang panjang konsep libido seksual yang dimiliki manusia itu sebagai

\footnotetext{
${ }^{21}$ Ibid.

${ }^{22}$ Ibid.
} 
sumber kejiwaan agama, rangkaian kisah ini akhirnya membentuk konsep tentang Tuhan beserta upacara keagamaanya. Kisah ini diangkat dari mitos masyarakat Yunani kuno. yang menceritakan kehidupan sebuah keluarga yang terdiri dari ayah, ibu dan anaknya yang bernama Oedipoes, mereka hidup rukun dan damai. Namun keharmonisan keluarga ini tidak bertahan lama, akhirnya menimbulkan rasa cemburu diantara mereka.

Sebagaimana ditulis Jalaluddin bahwa Oedipoes sangat mencintai ibunya dikarenakan rasa cemburunya terhadap ayahnya, lantas si anak membunuh ayahnya. Setelah ayahnya mati, maka timbullah rasa bersalah (sense of guilt) pada diri si anak, Rasa bersalah atas perbuatannya itu menimbulkan rasa penyesalan terhadap dirinya. Sebagai penebus atas dosa yang dilakukannya. Si anak melakukan pemujaan terhadap arwah sang ayah, karena ia takut akan pembalasan arwah ayahnya. Realisasi pemujaan ini, dalam agama dianggap sebagai awal dari upacara keagamaan. Rangkaian kisah ini disimpulkan Freud bahwa agama muncul dari illusi (khayalan) manusia. ${ }^{23}$

\section{Teori Fakulti}

Dalam teori fakulti sumber agama pada manusia adalah gabungan dari beberapa fungsi kejiwaan yang dimiliki manusia. Fungsi kejiwaan itu yang menggerakkan jiwa manusia untuk bertingkah laku keagamaan. Sebagaimana dikemukakan Jalaluddin bahwa tingkah laku manusia itu tidak bersumber pada satu faktor yang tunggal, tetapi terdiri dari berbagai unsur, antara lain yang dianggap memegang peranan penting adalah fungsi cipta (reason), rasa (emotion), dan karsa (will) ${ }^{24}$

Setiap perbuatan manusia yang bersifat keagamaan selalu dipengaruhi dan ditentukan oleh tiga fungsi kejiwaan yang ada pada manusia, yaitu: Cipta (reason) merupakn fungsi intelek jiwa manusia. Melalui fungsi cipta (reason) orang dapat membandingkan dan memutuskan suatu tindakan terhadap stimulus yang datang. Dalam agama modern peranan dan fungsi reason sangat menentukan perkembangan suatu agama, ajaran-ajaran agama yang tidak sesuai

\footnotetext{
${ }^{23}$ Ibid, h. 55-56.

${ }^{24}$ Ibid. h. 56
} 
dengan akal pemikiran menunjukkan agama yang kaku dan mati, karena tidak bisa mengikuti perkembangan dan kemajuan zaman. Bahkan fungsi cipta bagi penganutnya dapat pula menilai salah atau benar ajaran agamanya, selain itu fungsi cipta yang dimiliki oleh suatu agama sebagai landasan untuk meningkatkan intelek penganut suatu agama.

Kedua, rasa (emotion) merupakan tenaga dalam yang terdapat pada jiwa manusia yang mendorong manusia untuk berbuat sesuatu. Rasa (emotion) itu menurut Syaiful Hamali bahwa emosi adalah suatu keadaan yng bergejolak dalam diri individu yang berfungsi sebagai inner adjustment ( penyesuaian dari dalam ) terhadap lingkungan untuk mencapai kesejahteraan dan keselamatan individu. ${ }^{25}$ Rasa (emotion) yang terdapat dalam suatu agama harus dibantu oleh fungsi cipta (reason) agar emosi yang ada dalam diri manusia dapat dikendalikan, tetapi bila tidak maka emosi yang ada dalam diri manusia akan berbuat anarkhis karena ia berbuat dan bertindak tanpa kendali. Maka sikap yang dilakukannya ini niscaya akan mengurangi nilai-nilai agamanya bagi masyarakat. Emosi keagamaan bagi manusia merupakan sumber tingkah laku keagamaan. Koentjaraningrat menulis bahwa emosi keagamaan sebagai dasar dari setiap religi yang mendorong manusia berkelakuan serba religi, emosi keagamaan merupakan pusat kegiatan, penggerak munculnya kepercayaan, sistem upacara keagamaan, kelompok keagamaan ${ }^{26}$.

Ketiga, Karsa (will) berfungsi sebagai pelaksana pada jiwa manusia, karena karsa (will) mendorong seseorang untuk melaksanakan agamanya. Menurut Jalaluddin bahwa will berfungsi mendorong timbulnya pelaksanaan doktrin serta ajaran agama berdasarkan fungsi kejiwaan. ${ }^{27}$ Pengamalan keagamaan oleh seseorang harus memilik unsur kejiwaan, misalnya; tingkah laku keagamaan seseorang itu harus sesuai dengan ajaran agamanya serta mengimbangi tingkah laku, perbuatan, dan kehidupannya dengan kehendak Tuhan, berarti fungsi will yang dimilik oleh

${ }^{25}$ Syaiful Hamali, Eksistensi Beragama Dalam Perspektif Psikologi, (Bandar Lampung: Ushuluddin Offset Printing, 2000), h. 7.

${ }^{26}$ Koentjaraningrat, Beberapa Pokok..., h. 230.

${ }^{27}$ Jalaluddin, Psikologi..., h. 58. 
seseorang kuat. Sebaliknya bila tindak keagamaannya, tingkah laku, perbuatannya tidak sesuai dengan kehendak Tuhan menandakan fungsi will dalam dirinya lemah.

Berdasarkan sistem kerja dan fungsi kejiwaan yang terdapat pada manusia itu, maka dapat dipahami bahwa sumber kejiwaan agama pada manusia berasal dari ketiga fungsi kejiwaan yang ada pada manusia, hanya saja dalam pelakanaannya sangat diperlukan keserasian dan keseimbangan di antara fungsi kejiwaan tersebut, sehingga ajaran agama dapat dilaksanakan secara efesien dan baik.

Dasar pemikiran para pendukung teori fakulti tentang sumber kejiwaan agama pada manusia, adalah :

a. Konflik Kejiwaan

Manusia sebagai makhluk yang aktif dalam hidupnya selalu mengalami konflik kejiwaan, sebagaimana dijelaskan George M. Stratton bahwa sumber agama itu adalah konflik jiwa dalam diri individu. ${ }^{28}$ Konflik kejiwaan yang terjadi dalam diri manusia itu disebabkan terjadinya pertentangan jiwa dalam dirinya sendiri seperti; Pertentangan antara baik dan buruk, benci dan sayang, moral dan immoral dan sebagainya. Dampak pertentangan batin yang terjadi itu dapat dilihat dari dua sisi. Pertama, konflik kejiwaan yang terjadi itu dapat membawa manusia kepada kemajuan dalam hidupnya. Orang yang mengalami konflik kejiwaan berusaha mencarikan solusi untuk mengatasi masalahnya. Kedua, konflik kejiwaan yang terjadi itu dapat membawa manusia kepada kemunduran dalam hidupnya mereka tidak bisa menyelesaikan masalahnya. Dalam hal ini, Jalaludin sependapat dengan Sigmund Freud sebagaimana yang dituliskannya bahwa dalam setiap organis terdapat dua bentuk kejiwaan yang mendasar dalam diri manusia, yaitu: a) Life-urge; ialah keinginan untuk mempertahankan kelangsungan hidup dari keadaan yang terdahulu agar terus berlanjut; b) Death-urge; ialah keinginan untuk kembali ke keadaan semula sebagai benda mati ( anorganis). ${ }^{29}$

${ }^{28}$ Zakiah Daradjat, Ilmu Jiwa Agama, cet. ke-13, (Jakarta: Bulan Bintang, 1991), h. 19.

${ }^{29}$ Jalaluddin, Psikologi..., h. 59. 
Realitas dalam kehidupan masyarakat menunjukan bahwa kedua bentuk dorongan itu bagi manusia sangat berarti. Pertama, life-urge yaitu dorongan untuk mengamalkan agamanya dengan ketaatan dan keikhlasan sehingga disenangi oleh manusia dan Tuhan serta memohon agar dipanjangkan umurnya. Kedua, deathlife yaitu; dorongan untuk beramal dan beribadah dalam hidupnya, seolah-olah ia akan meninggalkan dunia ini, kemudian memohon agar segala amal ibadahnya diterima dan kelak ditempatkan di sisiNya di akhirat.

b. Kebutuhan-kebutuhan Dasar Manusia

Manusia sebagai makhluk membutuhkan banyak kebutuhan dalam hidupnya. Abraham H. Maslow dalam terori hirarki kebutuhan menjelaskan bahwa kebutuhan manusia pada dasarnya bertingkattingkat, mulai dari tingkat yang paling bawah sampai ke tingkat yang paling tinggi. Kebutuhan pada tingkat yang lebih tinggi tidak mungkin timbul sebelum kebutuhan yang lebih mendasar terpenuhi. ${ }^{30}$ Kebutuhan manusia itu adalah; Kebutuhan fisiologi, kebutuhan akan rasa aman (safety). Kebutuhan akan kasih sayang, kebutuhan akan harga diri, kebutuhan akan aktualisasi diri. Secara psikologis, gabungan dari kebutuhan-kebutuhan dasar manusia itu membentuk sumber keagamaan. Kebutuhan-kebutuhan manusia itu berkaitan erat dengan sikap keagamaan seseorang. Dengan terpenuhinya kebutuhan-kebutuhan tersebut manusia menjadi tenang dalam beragama, Suryabrata menulis pendapat Robert $\mathrm{H}$. Thouless bahwa: Saya berpendapat,masing-masing kebutuhan itu boleh jadi dengan penuh alasan dan bisa dianggap sebagai faktor yang mungkin ada dalam perkembangan sikap keagamaan itu ${ }^{31}$

\section{c. Keinginan Manusia}

Keinginan merupakan kehendak manusia yang berasal dari dalam jiwa manusia, bukan dari luar dirinya, ringkasnya keinginan adalah kehendak jiwa manusia. Sumadi Suryabrata menulis bahwa keinginan adalah perangsang psikologis. ${ }^{32}$ Maka keinginan itu

${ }^{30}$ Djamaluddin Ancok dan Fuat Nashori Suroso, Psikologi Islami..., h. 49.

${ }^{31}$ Sumadi Suryabrata, Psikologi Kepribadian, cet. ke-5, (Jakarta: CV. Rajawali. 1990), h. 62.

${ }^{32}$ Jalaluddin, Psikologi..., h. 62. 
merupakan sesuatu yang berasal dari dalam jiwa manusia yaitu kebutuhan biologis sebagai sumber penggerak ego dan super ego pada manusia.

W.H. Thomas dalam teori The Four Wishes menjelaskan bahwa yang menjadi sumber kejiwaan agama adalah empat macam keinginan dasar yang ada dalam jiwa manusia. ${ }^{33}$ Keinginan dasar manusia itu adalah keinginan untuk keselamatan (security), keinginan untuk mendapatkan penghargaan (recognition), keinginan untuk ditanggapi (response), keinginan akan pengetahuan atau pengalaman baru (new experience). Keempat keinginan dasar manusia itu merupakan stimulus dari manusia sedangkan keinginankenginan dasar itu dapat ditemui dalam agama,

\section{Penutup}

Dalam psikologi, kebutuhan dasar manusia berasal dari Id sebagai perangsang jasmani, berisikan instink-instink dan dorongandorongan agar semua kebutuhan itu segera dipenuhi, sehingga pada id berlaku prinsip kenikmatan. Kebutuhan manusia itu bertingkattingkat, mulai dari tingkat yang paling rendah sampai pada tingkat yang paling tinggi dan kebutuhan pada tingkatan yang tinggi belum bisa dicapai sebelum kebutuhan tingkat di bawahnya terpenuhi. Tingkatan kebutuhan manusia itu adalah kebutuhan fisologis, kebutuhan akan rasa aman, kebutuhan kasih sayang, kebutuhan akan harga diri dan kebutuhan akan aktualisasi diri.

Motivasi merupakan suatu kekuatan yang mendorong jiwa manusia untuk melakukan perbuatan-perbuatan dan tingkah laku keagamaan dalam hidupnya, sebagai upaya mereka untuk mengatasi berbagai bentuk ketidakberdayaan, ketidakpastian dan kecelakaan dalam hidupnya. Dalam konteks ini motivasi manusia beragama adalah untuk; Mengatasi frustrasi yang dialami manusia, mengatasi rasa takut, menjaga kesusilaan dalam masyarakat dan memuaskan intelek manusia.

Sedangkan sumber kejiwaan agama pada manusia terdiri dari teori monistik dan teori fakulti. Teori monistik menjelaskan bahwa sumber kejiwaan agama pada manusia berasal dari sumber

${ }^{33}$ Ibid. 
yang satu, sebagai dasar pemikiran mereka adalah: unsur berfikir pada manusia, sense of depende, libido seksual manusia. Sedangkan teori fakulti mengungkapkan bahwa sumber kejiwaan agama pada manusia merupakan gabungan dari beberapa fungsi kejiwaan, yaitu; fungsi cipta (reason), fungsi rasa (emotion), fungsi karsa (will), pendukung teori ini mengemukan konsep tentang konflik kejiwaan manusia, kebutuhan dasar manusia, keinginan-keinginan manusia.

\section{Daftar Pustaka}

Ahyadi, Abdul, Aziz, Psikologi Agama, Kepribadian Muslim Pancasila, Bandung: Sinar Baru, 1987.

Ancok, Djamalauddin dan Anshori Suroso, Fuat, cet. ke-1, Psikologi Islam, Jogyakarta: Pustaka Pelajar, 1994.

Bastamam, Djumhana Hanna, Integrasi Psikologi Dengan Islam Menuju Psikologi Islam, cet. ke-1,Yogyakarta: Pustaka Pelajar, 1997.

Daradjat, Zakiah, Ilmu Jiwa Agama, cet. ke-13, Jakarta: Bulan Bintang, 1991.

Peranan Agama Dalam Kesehatan Mental, Jakarta: Gunung Agung, 1970.

Deo'a, Thomas F. Sosiologi Agama, Suatu Pengenalan Awal, Terj. Yasogama, Jakarta: CV. Rajawali, Cet. I. 1985.

Driyarkara N, Percikan Filsafat, Jakarta: Pembangunan, 1983.

Hamali, Syaiful, Eksistensi Beragama Dalam Perspektif Psikologi Agama, Bandar Lampung: Ushuluddin Offset Printing, 2000.

Jalaluddin, Psikologi Agama, cet. ke-1, Jakarta: Raja Grafindo Persada, 1996.

Kartini, Kartono dan Andari, Jenny, Hygine Mental, Kesehatan Mental Dalam Islam, cet. ke-4, Bandung: Mandar Maju, 1996.

Koentjaraningrat, Beberapa Pokok Antropologi Sosial, cet. ke-4 Jakarta: Dian Rakyat, 1985. 
Nasution, Harun, Islam Ditinjau Dari Berbagi Aspek, cet. ke-2, Jakarta: UI. Press, 1984.

Nottingham, Elizbeth K, Agama dan Masyarakat, Suatu Pengantar Sosiologi Agama, Jakarta: Raja Grafindo Persada, 1993.

Puspito, Hedro, Sosiologi Agama, cet. ke-4, Jakarta: Kanisius, 1988.

Suryabrata, Sumadi, Psikologi Kepribadian, cet. ke-5, Jakarta: CV. Rajawali, 1990.

Syukur, Nico Diester, Pengalaman dan Motivasi Beragama, Pengantar Psikologi Agama, Jakarta: LEPPENAS, 1982.

Thouless, Robert H., Pengantar Psikologi Agama, Terj. Machnun Husien, cet. ke-1, Jakarta: CV. Rajawali, 1992. 
Syaiful Hamali

halaman ini bukan sengaja dikosongkan 